\title{
The role of the complement system in traumatic brain injury: a review
}

\author{
Adnan Hammad', Laura Westacott ${ }^{2}$ and Malik Zaben ${ }^{2 *}$ (D)
}

\begin{abstract}
Traumatic brain injury (TBI) is an important cause of disability and mortality in the western world. While the initial injury sustained results in damage, it is the subsequent secondary cascade that is thought to be the significant determinant of subsequent outcomes. The changes associated with the secondary injury do not become irreversible until some time after the start of the cascade. This may present a window of opportunity for therapeutic interventions aiming to improve outcomes subsequent to TBI. A prominent contributor to the secondary injury is a multifaceted inflammatory reaction. The complement system plays a notable role in this inflammatory reaction; however, it has often been overlooked in the context of TBI secondary injury. The complement system has homeostatic functions in the uninjured central nervous system (CNS), playing a part in neurodevelopment as well as having protective functions in the fully developed CNS, including protection from infection and inflammation. In the context of CNS injury, it can have a number of deleterious effects, evidence for which primarily comes not only from animal models but also, to a lesser extent, from human post-mortem studies. In stark contrast to this, complement may also promote neurogenesis and plasticity subsequent to CNS injury. This review aims to explore the role of the complement system in TBI secondary injury, by examining evidence from both clinical and animal studies. We examine whether specific complement activation pathways play more prominent roles in TBI than others. We also explore the potential role of complement in post-TBI neuroprotection and CNS repair/regeneration. Finally, we highlight the therapeutic potential of targeting the complement system in the context of TBI and point out certain areas on which future research is needed.
\end{abstract}

\section{Background}

Traumatic brain injury (TBI) is a leading cause of morbidity in the developed world, with an estimated 1.5-2 million Americans suffering from TBI each year and 52,000 dying as a consequence of TBI per year [1]. While medical advancements, including improvements in pre-hospital and critical care, have contributed greatly to a reduction in TBI-related mortality [2], it is still a leading cause of disability in the developed world, and a significant number of those who suffer from a TBI-related disability may require lifetime care. TBI is defined as damage to the brain resulting from an external force that causes the brain to move quickly within the skull. The damage that results is associated with an altered mental state. TBI can be classified as impact or non-impact. Impact TBI occurs when the

\footnotetext{
* Correspondence: zabenm@cardiff.ac.uk

${ }^{2}$ Neuroscience and Mental Health Research Institute (NMHRI), School of Medicine, Cardiff University, Room 4FT 80E, 4th Floor, Heath Park, Cardiff CF14 4XN, UK

Full list of author information is available at the end of the article
}

head is involved in a direct impact with an object. Nonimpact TBI occurs when there is no direct contact between the head and another object, but the head is still exposed to a force, as may occur in accelerationdeceleration injuries. TBI can also be classified on the basis of severity, according to the Glasgow Coma Scale (GCS), as mild, moderate or severe [3].

The initial mechanical impact associated with TBI results in a primary injury, subsequent to which a delayed secondary injury, normally develops [4]. This secondary injury is thought to be an important determinant of outcomes [5]. Thus, there may be a window of opportunity, between the start of the secondary injury cascade and the time at which these secondary changes become irreversible, during which medical intervention (e.g. pharmacologically) may improve outcomes. A major contributor to the secondary injury is neuroinflammation [6]. Microglia resident within the central nervous system (CNS) have been proposed to exist in two main states (M1 and M2), depending on the balance between pro- and anti-inflammatory mediators in 
the CNS milieu [7], though this view has been recently challenged (e.g. [8]). Pro-inflammatory mediators are believed to favor the M1 phenotype, with M1 microglia playing a crucial role in the clearance of cell debris as well as foreign antigens. However, M1 microglia can also result in damage to healthy cells, as well as releasing further proinflammatory mediators that can perpetuate and exacerbate the inflammatory reaction $[9,10]$. In contrast, anti-inflammatory mediators are thought to favor the M2 phenotype, which is associated with improved cellular survival and tissue repair $[11,12]$. Moreover, in vitro evidence suggests that M2 microglia are able to promote neurite outgrowth [13, 14]. Microglia express receptors for various complement components, including $\mathrm{C} 1 \mathrm{q}$ and $\mathrm{C} 3$ cleavage products, and thus the complement system plays a crucial role in microglial activation [15]. In pathological states with blood-brain barrier (BBB) compromise, there is evidence that $\mathrm{C} 1 \mathrm{q}$ contributes to a shift towards the M1 phenotype [16]. Mannose-binding lectin (MBL), part of the lectin pathway of complement activation, also appears to contribute to microglial activation, perhaps by promoting fibrin deposition [17]. It is thought that both M1 and M2 phenotype switching occurs in TBI, but it appears that there is a bias towards M1 over M2 in TBI secondary injury $[7,13]$. In addition to the direct damage induced by M1 microglia, the aforementioned pro-inflammatory cytokines they release can activate astrocytes [10]. While reactive astrocytes can have some protective effects in the CNS, e.g. through the release of neurotrophic factors [7, $18,19]$, the major result of astrocytic activation is the formation of glial scars [10]. Glial scars function as barriers to axonal regeneration and extension [7]. The initial injury also compromises the BBB, which permits the entry of peripheral circulating leukocytes, thereby further enhancing the inflammatory response [20,21]. A major component of the inflammatory response that is often overlooked, the complement system, is also activated as part of the neuroinflammatory response in TBI [22-24]. The endogenous CNS complement system is activated, and its activation is further enhanced by an influx of complement components from the circulation, aided by the breakdown of the BBB.

In addition to the neuroinflammatory response, the secondary injury in TBI is associated with a number of other changes that contribute to damage. Firstly, hypoperfusion of the penumbral region surrounding the core injury occurs. Thus, there is a mismatch between the metabolic requirements of cells in the penumbra and the cerebral blood flow to this area [25]. This mismatch disrupts the sodium-potassium $\left(\mathrm{Na}^{+}-\mathrm{K}^{+}\right)$pumps present in neuronal cell membranes, which results in transient depolarization of the cell membrane. Depolarization induces glutamate release [26], which can lead to excitotoxic neuronal death [27]. Excitotoxicity is associated with a rise in intracellular calcium $\left(\left[\mathrm{Ca}^{2+}\right]_{\mathrm{i}}\right)$, which activates a number of enzymes (e.g. proteases, phospholipases and endonucleases) that can damage the cell [28]. The rise in $\left[\mathrm{Ca}^{2+}\right]_{\mathrm{i}}$ also enhances the generation of free radicals, which can bring about further damage, including mitochondrial damage that can further exacerbate the oxidative stress [29].

This review will focus particularly on the role the complement system plays during TBI secondary injury. The complement system is now thought to have both deleterious effects and neuroprotective effects in the CNS, and this review will explore the balance between them in the context of TBI secondary injury. The review will also explore the literature concerning attempts to modulate the complement system in the context of TBI secondary injury to explore whether this has had any impact on post-injury outcomes.

\section{Overview of the complement system}

The complement system is traditionally viewed as part of the innate immune system that, along with the adaptive immune system, is involved in protecting the body from foreign antigens [30]. It encompasses more than 30 proteins (both cell surface-bound and soluble) that are zymogens. There is significant amplification in the cascade, as once these zymogens have been activated, the resulting active enzymes can then go on to repeatedly act on their substrates [31].

The complement system can be activated via any one of three different pathways: the classical, alternative and lectin pathways [32] (see Fig. 1). Another pathway that can lead to complement activation is the extrinsic pathway of the coagulation cascade [33]. The classical pathway is activated by $\mathrm{Clq}$ binding to the fragment crystallizable (Fc) region of IgG and/or IgM antibodies bound to antigens to which they are reactive. $\mathrm{C} 1 \mathrm{r}$ and $\mathrm{C} 1 \mathrm{~s}$ then bind to $\mathrm{C} 1 \mathrm{q}$ to form a C1qrs complex, with the C1s component cleaving $\mathrm{C} 4$ to $\mathrm{C} 4 \mathrm{a}$ and $\mathrm{C} 4 \mathrm{~b}$, and $\mathrm{C} 2$ to $\mathrm{C} 2 \mathrm{a}$ and $\mathrm{C} 2 \mathrm{~b}$. $\mathrm{C} 2 \mathrm{~b}$ can subsequently associate with $\mathrm{C} 4 \mathrm{~b}$ to form $\mathrm{C} 4 \mathrm{bC} 2 \mathrm{~b}$, which functions as a $\mathrm{C} 3$ convertase. The $\mathrm{C} 3$ convertase cleaves $\mathrm{C} 3$ to $\mathrm{C} 3 \mathrm{a}$ and $\mathrm{C} 3 \mathrm{~b}$, with $\mathrm{C} 3 \mathrm{a}$ being an anaphylatoxin. Anaphylatoxins can induce histamine release from mast cells, smooth muscle contraction and can increase vascular permeability. They are also involved in mediating chemotaxis. $\mathrm{C} 3 \mathrm{~b}$ is an opsonin, which enhances the phagocytosis of apoptotic cells and pathogens. The lectin pathway also generates the same $\mathrm{C} 3$ convertase, but via a different mechanism. In this pathway, bacterial carbohydrate motifs are bound by MBL. MBL-associated serine proteases (MASPs) then cleave $\mathrm{C} 4$ and $\mathrm{C} 2$, generating $\mathrm{C} 4 \mathrm{bC} 2 \mathrm{~b}$. The alternative pathway, like the classical pathway, leads to continuous tickover of complement (i.e. its activation at a low background rate). In this pathway, $\mathrm{C} 3$ reacts with water to produce $\mathrm{C} 3\left(\mathrm{H}_{2} \mathrm{O}\right)$. Factors $\mathrm{B}(\mathrm{fB})$ and $\mathrm{D}(\mathrm{fD})$ are then recruited, with $\mathrm{fD}$ cleaving $\mathrm{fB}$ to generate $\mathrm{fBb}$. $\mathrm{fBb}$ can bind to $\mathrm{C} 3 \mathrm{~b}$ to generate the alternative 


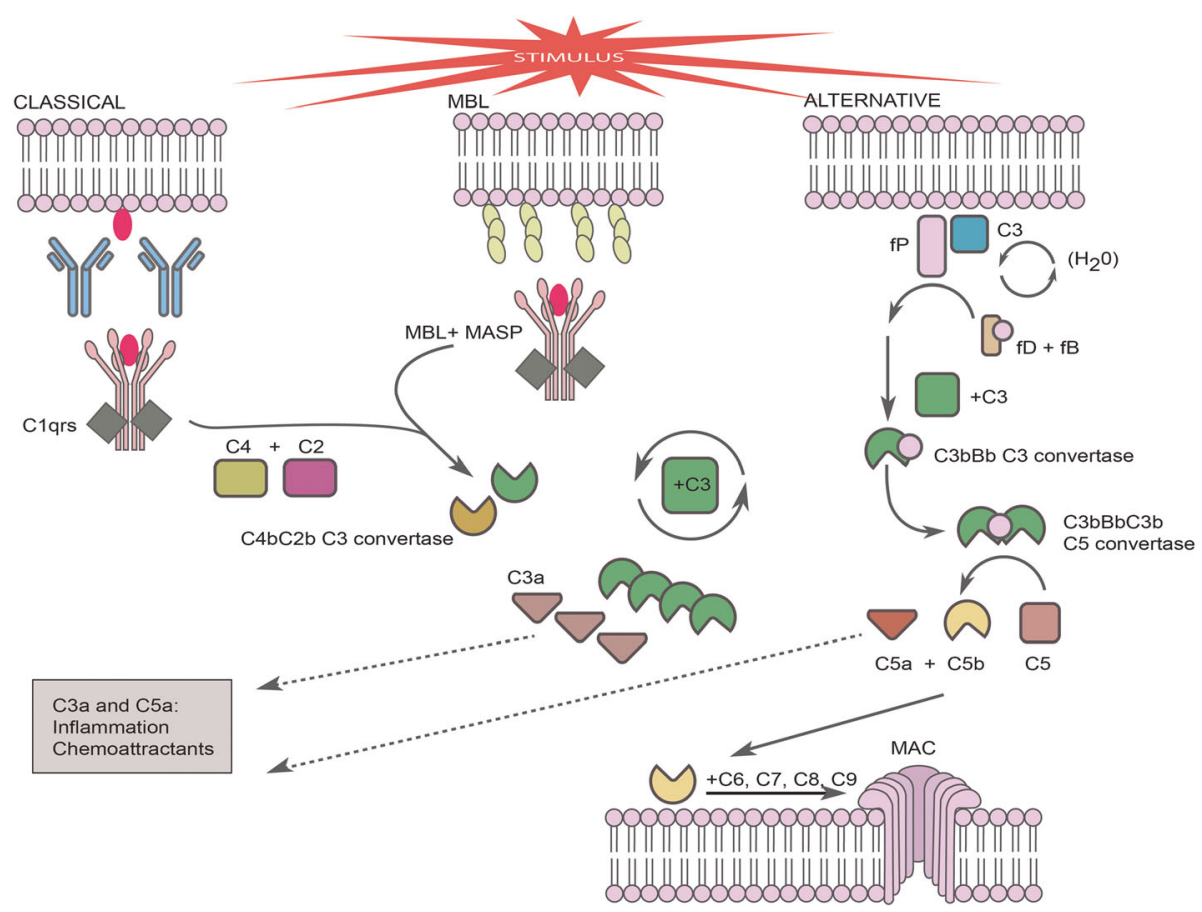

Fig. 1 Schematic illustration of the complement cascade. The three activation pathways, the classical, alternative and lectin (MBL) pathways, are all included. Shown are the anaphylatoxins (C3a and C5a), which can trigger mast cell degranulation, and the MAC, which can lead to cell lysis. Adapted from Mathern and Heeger, 2015 [28]

pathway $\mathrm{C} 3$ convertase, $\mathrm{C} 3 \mathrm{bBb}$. The regulator properdin is able to stabilise this convertase [34]. Both convertases, $\mathrm{C} 3 \mathrm{bBb}$ and $\mathrm{C} 4 \mathrm{~b} 2 \mathrm{~b}$, can recruit further $\mathrm{C} 3 \mathrm{~b}$ molecules and form complexes with them. These complexes, $\mathrm{C} 3 \mathrm{bBbC} 3 \mathrm{~b}$ and $\mathrm{C} 4 \mathrm{~b} 2 \mathrm{bC} 3 \mathrm{~b}$, function as $\mathrm{C} 5$ convertases. This results in the formation of $\mathrm{C} 5 \mathrm{a}$ (which is another anaphylatoxin) and C5b. The formation of C5b can initiate the formation of the membrane attack complex (MAC), by binding to C6, C7, C8 and 10-16 C9 molecules to form C5b-9. The resulting $\mathrm{MAC}$ complex can insert into the membranes of cells, resulting in the lysis of non-nucleated cells as well as having milder effects on nucleated cells [31, 35]. C5a is a powerful pro-inflammatory molecule, augmenting the production of various chemokines, cytokines, reactive oxygen species (ROS) as well as mediators such as prostaglandins. It is also capable of acting as a chemoattractant, by upregulating leukocyte adhesion molecules on endothelial cells, thereby enhancing the extravasation of leukocytes into foci of inflammation and/or infection [36]. The complement system also appears to take part in regulating the adaptive immune system, including both $\mathrm{T}$ cells and $\mathrm{B}$ cells. There is evidence that complement contributes to the regulation of $\mathrm{T}$ cell activation and proliferation [37, 38]. Similarly, complement facilitates the activation of $B$ cells and enhances the survival of memory B cells [39-41].

In addition to extracellular complement activation, it has become apparent that the complement cascade can be activated intracellularly too $[42,43]$. Human T helper cells store C3 intracellularly. They also contain cathepsin L (CTSL) and C3a receptors (C3aRs). CTSL cleaves C3, generating $\mathrm{C} 3 \mathrm{a}$ and $\mathrm{C} 3 \mathrm{~b}$. $\mathrm{C} 3 \mathrm{a}$ then binds to $\mathrm{C} 3 \mathrm{aRs}$, which has an important function in T cell survival [44]. Since this discovery was made, it has emerged that $\mathrm{T}$ cells also possess intracellular C5 stores [43]. Intracellular C5 is cleaved by an as yet unidentified enzyme to generate $\mathrm{C} 5 \mathrm{a}$. C5a can then bind to $\mathrm{C} 5$ a receptor 1 (C5aR1), which results in inflammasome activation as well as increased production of ROS by T cells [45].

The activation of the complement system must be tightly regulated, in order for it to only be activated when required (i.e. in the presence of a foreign antigen) and so that it is not erroneously activated (see Fig. 2). A number of mechanisms exist that regulate the activity of the convertases. One such mechanism involves decay accelerating factor (DAF), which accelerates the breakdown of both C3 and $\mathrm{C} 5$ convertases associated with the cell membrane [46], thereby also interfering with MAC formation [47]. Similarly, serum factor I (fI) in concert with membrane cofactor protein (MCP) acts to cleave $\mathrm{C} 3 \mathrm{~b}$ to $\mathrm{iC} 3 \mathrm{~b}$, which inactivates the $\mathrm{C} 3$ convertase [48]. The final mechanism that acts at the $\mathrm{C} 3$ convertase stage involves factor $\mathrm{H}(\mathrm{fH})$, which binds to $\mathrm{C} 3 \mathrm{~b}$ attached to the cell membrane and accelerates its breakdown [49]. Further mechanisms that are involved in complement regulation include the inhibition 


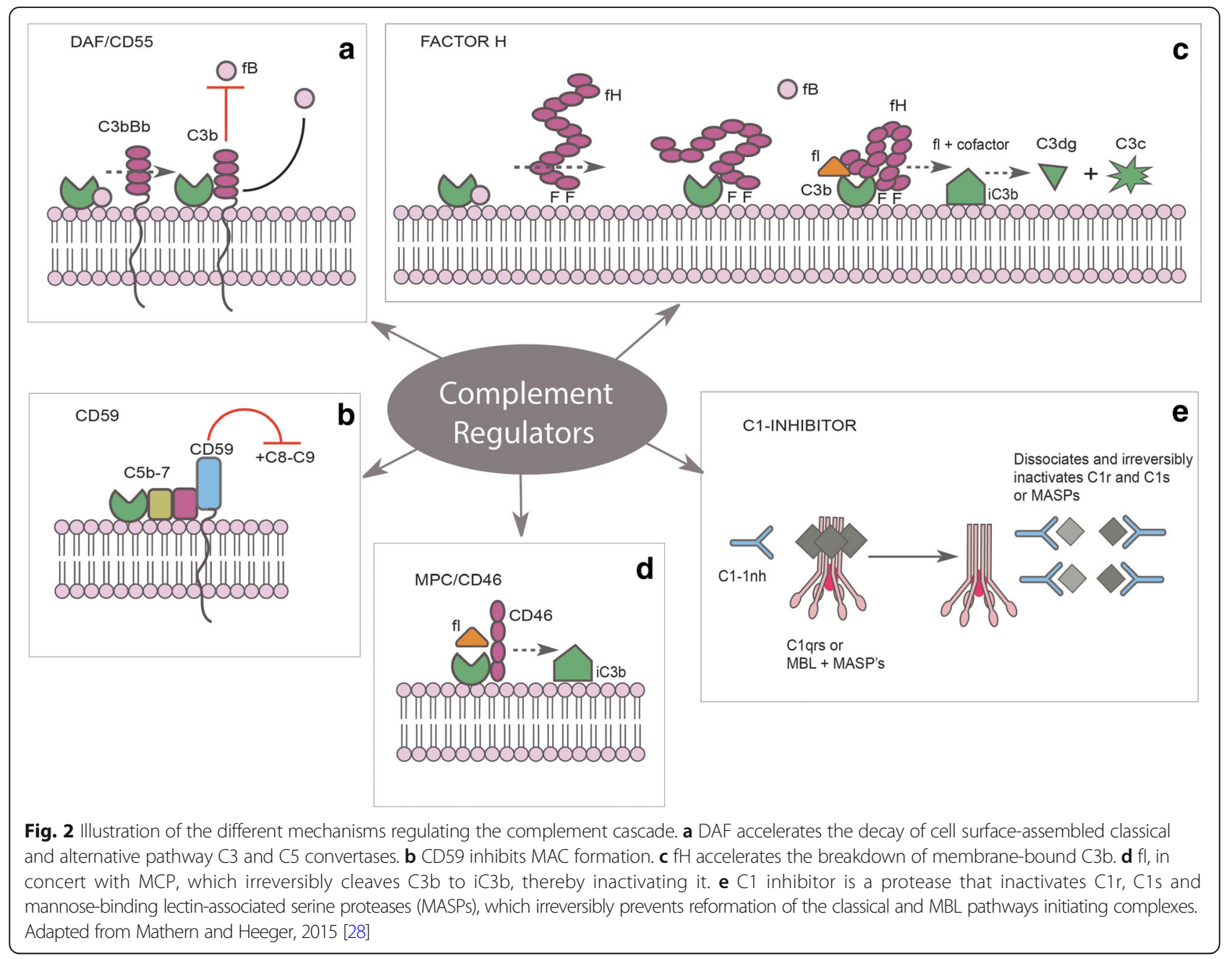

of MAC formation by CD59, and the inhibition of the classical and lectin pathways by $\mathrm{C} 1$ inhibitor (C1-INH). CD59 is believed to inhibit MAC formation by blocking the polymerization of $\mathrm{C} 9$ and its association with C5b678 [49].

\section{The complement system in the healthy CNS}

Given that the brain and spinal cord are surrounded by the BBB and blood-spinal cord barrier (BSB), respectively, it would be expected that circulating plasma complement components should be mostly excluded from the CNS. However, it has been known for a long time that components of the complement cascade are present within the CNS [50], with a number of studies demonstrating that both neurons and glial cells are capable of synthesizing them $[51,52]$. Similarly, a number of studies have shown that complement receptor expression is widespread within the CNS, with mRNA encoding receptors for C3a and C5a being expressed widely [53-55].

The complement system plays a number of vital roles in brain homeostasis [56]. Complement is involved in the clearance of cellular debris as well as cells undergoing apoptosis [56]. It is also thought to play a role in the clearance of amyloid $\beta(A \beta)$ plaques, deposition of which is associated with ageing and Alzheimer's disease, via opsonization of the deposited proteins thereby rendering them more susceptible to phagocytosis by resident microglia [57]. Moreover, the complement system has been implicated in protecting the CNS from infection and inflammation. Experiments carried out in a murine model of pneumococcal meningitis have demonstrated that mice lacking either of complement components $\mathrm{C} 1 \mathrm{q}$ or $\mathrm{C} 3$ are more susceptible to Streptococcus pneumoniae infections affecting the CNS compared to controls [58]. Similarly, C3a/glial fibrillary acidic protein (C3a/GFAP) mice, which have restricted overexpression of $\mathrm{C} 3 \mathrm{a}$ in the $\mathrm{CNS}$, were less susceptible to mortality subsequent to endotoxin/LPS-induced shock than wildtype and C3a receptor (C3aR) deficient mice [59]. In support of these observations, bacterial infection and/or inflammation were found to lead to the upregulation of complement mRNA expression in the CNS $[60,61]$.

More recently, further roles for the complement system in the CNS under physiological conditions, including 
developmental functions, have been revealed [56]. Evidence that complement is involved in synaptic pruning during development came primarily from murine studies on the development of the retinogeniculate pathway. These studies demonstrated that complement components $\mathrm{C} 1 \mathrm{q}$ and $\mathrm{C} 3$, released by astrocytes, opsonize synapses that are to be eliminated thereby rendering them more susceptible to phagocytosis by microglia [62-64]. $\mathrm{Clq}^{-/-}$, $\mathrm{C}^{-1-}$ and $\mathrm{C} 4^{-/-}$mice all possessed excess synapses and showed reduced synaptic pruning compared to wildtypes $[62,65,66]$. C1q knockout $\left(\mathrm{C}^{\mathrm{q}}{ }^{-/-}\right)$mice have a greater incidence of epileptogenesis than wildtypes, as indicated both by epileptiform activity on electroencephalogram (EEG) as well as behavioral seizure activity [64]. Complement also appears to be involved in cerebellar development, for which there is evidence from experiments in neonatal rats. It was found that the expression of both C3aRs and C5a receptors (C5aRs) increased postnatally in cerebellar granule cells, reaching a peak on postnatal day 12 (P12) [67]. Moreover, administration of a C3aR agonist to neonatal rats was associated with an increase in the thickness of the internal granule cell layer and a concomitant decrease in the thickness of the external granule cell layer. This suggests that C3a might normally be involved in facilitating granule cell migration from the external to the internal granule cell layer. In contrast, C5aR agonist administration was associated with an increase in the thickness of the external granule cell layer. It was also associated with enhanced survival of granule cells, secondary to a reduction in the activity of caspase- 9 , which functions as an apoptosis initiator $[67,68]$.

\section{The complement system and CNS injury}

When the CNS is subjected to an insult that results in injury, a cascade of secondary pathophysiological events is induced, a key part of which is a prominent neuroinflammatory response. These secondary events compromise the integrity of the neurons present in the penumbral region, which would not have been directly affected by the primary insult to the injured core [69]. Much attention has been directed at the role of the adaptive immune response in secondary injury (e.g. [70]), but there has been more recent interest in the complement system as an important player in secondary injury $[71,72]$.

\section{Clinical studies}

Traumatic injuries to both the brain and spinal cord are accompanied by a breakdown of the BBB and BSB, respectively. Therefore, in addition to the fairly low levels of complement components expressed endogenously in the brain/spinal cord, there is a massive influx of serum proteins, including complement components (see Table 1 for a summary). There is also an influx of various innate and adaptive immune cells that are able to contribute to complement activation [69]. The complement system appears to play a particularly significant role in the secondary injury that occurs in the context of TBI. Frontal and temporal lobes resected from TBI patients were probed by immunohistochemistry for the presence of complement components. It was found that the levels of $\mathrm{C} 1 \mathrm{q}, \mathrm{C} 3 \mathrm{~b}, \mathrm{C} 3 \mathrm{~d}$ and MAC were elevated in the penumbral regions of the injured area compared to controls [23]. Similar results were observed in animal models of TBI [22]. These findings were supported by the observation that a number of complement components, e.g. C3, $\mathrm{C} 1 \mathrm{q}$ and $\mathrm{fB}$, were raised in the cerebrospinal fluid (CSF) of TBI patients compared to controls [73, 74]. Similarly, MAC levels were significantly raised in the CSF of TBI patients compared to controls [24]. Moreover, MBL immunostaining in TBI patients was observed around blood vessels in brain tissue that had undergone TBI injury, with no staining observed in controls [75].

\section{Animal studies}

Evidence for complement involvement in TBI secondary injury comes from a variety of animal models (see Table 2 for a summary). While the majority of the studies discussed below use various models of TBI, two make use of intracerebral hemorrhage (IHC), which is a model of hemorrhagic stroke. Therefore, the degree to which the results of these two experiments are generalizable to TBI is open to debate. The other models used to mimic TBI; cryoinjury, controlled cortical impact (CCI) and standardized weight drop, also vary in their ability to mimic various aspects of TBI. For example, while cryoinjury induces cerebral edema and BBB compromise, both of which are features of TBI [76], the mechanism of injury is not mechanical as in TBI. In contrast, standardized weight-drop models more faithfully mimic the mechanical injury seen in TBI, but they have the disadvantage of low reproducibility/reliability [77]. Therefore, the applicability of these models to human TBI is debatable, and the interpretation of results obtained using such models in the context of human TBI should only be done with great care. CCI, like standardized weight-drop models, mimics the mechanical mechanism of injury of TBI, and has the advantage over other TBI models of versatility, such that the depth and velocity of the impact can be controlled more easily. The results are therefore more highly reproducible [77]. Moreover, the pathological changes seen with this model closely mimic those seen in TBI itself [78]. Therefore, results obtained using this model may be more applicable to humans, but care should still be taken even when drawing conclusions from studies based on this model.

The earliest animal study investigating the involvement of the complement system in TBI secondary injury involved the administration to rats of soluble complement 
Table 1 Summary of clinical studies investigating the role of complement in TBI

\begin{tabular}{|c|c|c|c|c|c|}
\hline Study & Type of brain insult & Controls & Assay & $\begin{array}{l}\text { Complement } \\
\text { pathway(s) }\end{array}$ & Relevant finding(s) \\
\hline $\begin{array}{l}\text { Bellander et al., } \\
2001 \text { [23] }\end{array}$ & $\begin{array}{l}\text { Cerebral contusion } \\
(n=16)\end{array}$ & $\begin{array}{l}\text { Epileptic patients undergoing } \\
\text { hippocampectomy }(n=3)\end{array}$ & $\begin{array}{l}\text { Immunohistochemistry } \\
(\mathrm{IHC}) \text { for C1q, C3b, C3d } \\
\text { and MAC; in situ } \\
\text { hybridization for C3 } \\
\text { mRNA }\end{array}$ & All & $\begin{array}{l}\text { Increased immunoreactivity } \\
\text { for C1q, C3b, C3d and the } \\
\text { MAC in the immediate vicinity } \\
\text { of neurons in the penumbra } \\
\text { area of the contusion in the } \\
\text { patient group. In situ } \\
\text { hybridization revealed C3 } \\
\text { mRNA in the penumbra. }\end{array}$ \\
\hline $\begin{array}{l}\text { Kossmann et al., } \\
1997[74]\end{array}$ & $\begin{array}{l}\text { Severe TBI }(n=13) \text { : } \\
\text { closed head injury } \\
(n=12) \text {; open head } \\
\text { injury }(n=1)\end{array}$ & $\begin{array}{l}\text { Patients undergoing diagnostic } \\
\text { lumbar puncture }(n=22)\end{array}$ & $\begin{array}{l}\text { Radioimmunoassay } \\
\text { (RIA) or enzyme linked } \\
\text { immunosorbent assay } \\
\text { (ELISA) for C3 and fB }\end{array}$ & All & $\begin{array}{l}\text { Elevated levels of C3 and } \\
\text { fB in CSF of TBI patients } \\
\text { compared to controls. }\end{array}$ \\
\hline $\begin{array}{l}\text { Stahel et al., } \\
2001[24]\end{array}$ & $\begin{array}{l}\text { Severe TBI (closed } \\
\text { head injury) }(n=11)\end{array}$ & $\begin{array}{l}\text { Patients, without any known } \\
\text { head trauma or inflammatory } \\
\text { neurological disease, undergoing } \\
\text { diagnostic spinal tap }(n=12)\end{array}$ & ELISA for sC $5 b-9$ & All & $\begin{array}{l}\text { Raised mean sC5b-9 levels } \\
\text { in CSF of } 10 \text { out of } 11 \mathrm{TBI} \\
\text { patients compared to CSF } \\
\text { obtained from controls. }\end{array}$ \\
\hline $\begin{array}{l}\text { Longhi et al., } \\
2014 \text { [75] }\end{array}$ & $\begin{array}{l}\text { Cerebral contusion } \\
(n=6)\end{array}$ & $\begin{array}{l}\text { Non-TBI patients who received } \\
\text { surgery for brain tumors }(n=2)\end{array}$ & $I H C$ for $M B L$ & Lectin & $\begin{array}{l}\text { MBL-positive staining was } \\
\text { observed in brain tissue } \\
\text { samples from cerebral } \\
\text { contusion patients, but not } \\
\text { in equivalent samples from } \\
\text { controls. }\end{array}$ \\
\hline
\end{tabular}

receptor 1 (sCR1), which, by suppressing C3 convertase formation, inhibits the classical, lectin and alternative complement activation pathways. Rats treated with sCR1 had reduced brain neutrophil infiltration compared to vehicle-treated rats, suggesting that complement plays a pivotal role in the neuroinflammatory response induced by TBI. [79] These findings were supported by studies performed on $\mathrm{C} 3$ null $\left(\mathrm{C}^{-l-}\right)$ mice. When these mice were exposed to an $\mathrm{ICH}$ injury, reduced leukocyte infiltration, microglial activation and edema build-up were observed in the penumbral region surrounding the site of injury, when compared with control mice. This was paralleled by a reduced motor deficit in the affected limb compared to controls [80]. Similar results were obtained with $\mathrm{C} 3$ null mice exposed to cryoinjury [81]. In a CCI model of TBI, $\mathrm{C}^{-1-}$ mice were found to have reduced brain leukocyte infiltration compared to wildtypes, but there were no differences between them with regard to injury size or neurological deficits [82]. CNS-restricted overexpression of complement receptor type 1-related protein y (Crry), which inhibits C3 convertase formation, resulted in better neurological outcomes when compared with control mice, even up to 4 weeks after the initial injury [83]. Based on these results, recombinant Crry (Crry-Ig) was administered to mice that had undergone a form of closed head injury. Reduced tissue loss as well as improved neurological outcomes was found in these mice, compared with vehicle-treated mice that had undergone the same type of injury, when Crry-Ig was administered 1 and $24 \mathrm{~h}$ after the initial injury [84].

Animal models have also been used to investigate the role of the anaphylatoxins (i.e. C3a and C5a) in TBI secondary injury. Interfering with the function of C5a, e.g. in $\mathrm{C} 5$ null $\left(\mathrm{C}^{-/-}\right)$mice or by administering an antagonist of $\mathrm{C} 5 \mathrm{aR}$, reduced secondary damage in a cryoinjury model of TBI [81]. Furthermore, administration of another C5aR antagonist, [hexapeptide-derived macrocycle AcF (OPdChaWR)], in an ICH model was found to improve spatial memory (as measured by performance in the Morris water maze) as well as general neurological function, when compared with vehicle-treated controls. This was paralleled by a reduction in leukocyte infiltration and edema in the vicinity of the lesion [85]. When the C5aR antagonist was combined with a C3aR antagonist, SB290157, a synergistic neuroprotective effect was observed [85]. However, the fact that SB290157 can also function as a C3aR agonist in particular cells, thought to have a high density of C3aRs, complicates the interpretation of the aforementioned result $[86,87]$.

Similarly, animal studies have revealed a prominent role for the MAC in secondary injury following TBI. The role of the MAC was investigated using CD59 null (CD59 ${ }^{-/-}$) mice, which displayed increased MAC attachment to cell membranes due to the absence of the MAC regulatory protein, CD59. When these mice were exposed to a focal closed head injury, they displayed increased neuronal loss and worse neurological outcomes when compared to controls that had undergone the same injury [88]. In contrast, interfering with $\mathrm{MAC}$ formation by administrating $\mathrm{OmCI}$, a complement inhibitor that binds $\mathrm{C} 5$, was found to reduce neuronal death, microglial activation and neurological deficits in a TBI mouse model when compared with vehicle-treated controls. Administration of a C6 antisense oligonucleotide, which blocks MAC formation by 
Table 2 Summary of studies investigating the role of complement in TBI using animal models

\begin{tabular}{|c|c|c|c|c|c|}
\hline Study & Species & Model & Treatment & $\begin{array}{l}\text { Complement } \\
\text { pathway(s) }\end{array}$ & Relevant finding(s) \\
\hline $\begin{array}{l}\text { Kaczorowski } \\
\text { et al., } 1995 \text { [79] }\end{array}$ & Rat & $\begin{array}{l}\text { Standardized } \\
\text { weight-drop }\end{array}$ & $\begin{array}{l}\cdot W T+\text { sCR1 } \\
\cdot W T+\text { vehicle }\end{array}$ & All & $\begin{array}{l}\text { Rats treated with sCR1 had reduced brain } \\
\text { neutrophil infiltration compared to vehicle-treated } \\
\text { rats, suggesting that complement plays a role in the } \\
\text { neuroinflammatory response induced by TBI. }\end{array}$ \\
\hline $\begin{array}{l}\text { Yang et al., } \\
2006 \text { [80] }\end{array}$ & Mouse & $\begin{array}{l}\text { Intracerebral } \\
\text { hemorrhage (ICH) }\end{array}$ & $\begin{array}{l}\cdot \mathrm{C}^{-/-} \\
\cdot \mathrm{WT}\end{array}$ & All & $\begin{array}{l}\mathrm{C} 3^{-1-} \text { mice, when compared with WT mice, showed } \\
\text { reduced brain oedema, lower hemeoxygenase-1 } \\
\text { levels, and reduced microglia activation and } \\
\text { neutrophil infiltration after injury. The } \mathrm{C}^{-1-} \text { mice } \\
\text { also displayed reduced forelimb dysfunction in } \\
\text { comparison with WT mice. }\end{array}$ \\
\hline $\begin{array}{l}\text { Sewell et al., } \\
2004 \text { [81] }\end{array}$ & Mouse & Cryoinjury & $\begin{array}{l}\cdot \mathrm{C}^{-/-} \\
\cdot \mathrm{C}^{-/-} \\
\cdot \mathrm{WT}+\mathrm{C} 5 \mathrm{aR} \text { antagonist } \\
\cdot \mathrm{WT}\end{array}$ & All & $\begin{array}{l}\text { Injury size and neutrophil infiltration were significantly } \\
\text { reduced in } \mathrm{C}^{-1-} \text { mice compared with WT mice. } \\
\text { Neutrophil infiltration was also found to be reduced } \\
\text { in } C 5^{-1-} \text { mice and WT mice treated with a C5aR } \\
\text { antagonist compared with untreated WT mice. }\end{array}$ \\
\hline $\begin{array}{l}\text { Rancan et al., } \\
2003 \text { [83] }\end{array}$ & Mouse & $\begin{array}{l}\text { Standardized } \\
\text { weight-drop model } \\
\text { (focal closed head injury) }\end{array}$ & $\begin{array}{l}\cdot \text { - GFAP-sCrry } \\
\cdot W T\end{array}$ & All & $\begin{array}{l}\text { GFAP-sCrry mice were found to have reduced } \\
\text { neurological deficits and BBB compromise compared } \\
\text { with WT mice exposed to the same TBI-like injury. }\end{array}$ \\
\hline $\begin{array}{l}\text { Leinhase et al., } \\
\text { 2006a [84] }\end{array}$ & Mouse & $\begin{array}{l}\text { Standardized } \\
\text { weight-drop }\end{array}$ & $\begin{array}{l}\cdot W T+\text { Crry-lg } \\
\cdot W T+\text { vehicle }\end{array}$ & All & $\begin{array}{l}\text { Administration of Crry-lg } 1 \text { and } 24 \text { hrs after injury } \\
\text { was associated with a reduction in tissue loss and } \\
\text { improvement in neurological function when } \\
\text { compared with vehicle-treated mice. }\end{array}$ \\
\hline $\begin{array}{l}\text { Garrett et al., } \\
2009 \text { [85] }\end{array}$ & Mouse & $\mathrm{ICH}$ & $\begin{array}{l}\cdot W T+C 5 a R \text { antagonist } \\
\cdot W T+C 5 a R \text { antagonist } \\
+ \text { C3aR antagonist } \\
\cdot \text { WT + vehicle }\end{array}$ & All & $\begin{array}{l}\text { Administration of a C5aR antagonist alone, or both } \\
\text { C5aR and C3aR antagonists, to WT mice was associated } \\
\text { with a reduced deficit in neurological function and } \\
\text { reduced spatial memory dysfunction compared with } \\
\text { vehicle-treated WT mice. These effects were also } \\
\text { associated with a reduction in leukocyte infiltration } \\
\text { and oedema A synergistic effect was observed upon } \\
\text { administration of both antagonists. }\end{array}$ \\
\hline $\begin{array}{l}\text { Stahel et al., } \\
2009 \text { [88] }\end{array}$ & Mouse & $\begin{array}{l}\text { Standardized } \\
\text { weight-drop }\end{array}$ & $\begin{array}{l}\text { - CD } 59 a^{-/-} \\
\text {- WT }\end{array}$ & All & $\begin{array}{l}\text { CD95a } a^{-1-} \text { mice had significantly worse neurological } \\
\text { outcomes than WT mice } 7 \text { days post-injury. Neuronal } \\
\text { cell death in CD59a } a^{-1-} \text { mice was also greater than that } \\
\text { in WT mice, as indicated both by serum NSE levels as } \\
\text { well as TUNEL histochemistry. }\end{array}$ \\
\hline $\begin{array}{l}\text { Fluiter et al., } \\
2014 \text { [89] }\end{array}$ & Mouse & $\begin{array}{l}\text { Standardized } \\
\text { weight-drop }\end{array}$ & $\begin{array}{l}\cdot W T+\mathrm{OmCl} \\
\cdot \mathrm{WT}+\mathrm{C} 6 \text { antisense } \\
\cdot \mathrm{WT}+\text { vehicle }\end{array}$ & All & $\begin{array}{l}\text { Interfering with MAC formation, by administering OmCl } \\
\text { or C6 antisense to WT mice, was associated with a } \\
\text { reduction in neuronal death, microglial activation and } \\
\text { neurological deficit, compared with vehicle-treated } \\
\text { WT mice. }\end{array}$ \\
\hline $\begin{array}{l}\text { Ruseva et al., } \\
2015 \text { [90] }\end{array}$ & Mouse & $\begin{array}{l}\text { Standardized } \\
\text { weight-drop }\end{array}$ & $\begin{array}{l}\cdot W T+\text { CD59-2a-CRlg } \\
\cdot W T+\text { vehicle }\end{array}$ & All & $\begin{array}{l}\text { CD59-2a-CRlg was found to inhibit MAC formation } \\
\text { in vitro. In vivo administration of CD59-2a-CRlg reduced } \\
\text { MAC formation, neuronal damage, and microglial } \\
\text { activation compared to vehicle treated controls. } \\
\text { Neurological outcomes were ameliorated with } \\
\text { CD59-2a-CRlg administration. }\end{array}$ \\
\hline $\begin{array}{l}\text { Leinhase et al., } \\
\text { 2006b [91] }\end{array}$ & Mouse & $\begin{array}{l}\text { Standardized } \\
\text { weight-drop }\end{array}$ & $\begin{array}{l}\cdot \mathrm{fB}-/- \\
\cdot \mathrm{WT}\end{array}$ & Alternative & $\begin{array}{l}\mathrm{fB}^{-/-} \text {mice were found to have reduced neuronal loss, } \\
\text { upregulation of the anti-apoptotic regulatory protein } \\
\mathrm{BCl}-2 \text {, and downregulation of the pro-apoptotic Fas } \\
\text { receptor, compared with WT mice subsequent to a } \\
\text { TBI-like injury. }\end{array}$ \\
\hline $\begin{array}{l}\text { Leinhase et al., } \\
2007 \text { [92] }\end{array}$ & Mouse & $\begin{array}{l}\text { Standardized } \\
\text { weight-drop }\end{array}$ & $\begin{array}{l}\cdot W T+\text { mab1379 } \\
\cdot W T\end{array}$ & Alternative & $\begin{array}{l}\text { Administration of mab1379, a monoclonal antibody } \\
\text { directed against fB, } 1 \text { or } 24 \text { hrs after injury was } \\
\text { associated with reduced neuronal loss, an attenuated } \\
\text { inflammatory response, as well as upregulation of genes } \\
\text { associated with neuroprotection, in comparison with } \\
\text { vehicle administration. }\end{array}$ \\
\hline
\end{tabular}


Table 2 Summary of studies investigating the role of complement in TBI using animal models (Continued)

\begin{tabular}{|c|c|c|c|c|c|}
\hline Study & Species & Model & Treatment & $\begin{array}{l}\text { Complement } \\
\text { pathway(s) }\end{array}$ & Relevant finding(s) \\
\hline $\begin{array}{l}\text { You et al., } \\
2007 \text { [82] }\end{array}$ & Mouse & $\begin{array}{l}\text { Controlled cortical } \\
\text { impact (CCl) }\end{array}$ & $\begin{array}{l}\cdot \mathrm{Cl}^{-1-} \\
\cdot \mathrm{C}^{-/-} \\
\cdot \mathrm{CH}^{-1-}+\mathrm{hC} 4 \\
\cdot \mathrm{WT}\end{array}$ & $\begin{array}{l}\text { - All (C3) } \\
\text { - Classical and } \\
\text { lectin (C4) }\end{array}$ & $\begin{array}{l}\mathrm{C}^{---} \text {mice were found to have reduced brain } \\
\text { leukocyte infiltration compared to WT, but there } \\
\text { were no differences between them in terms of injury } \\
\text { size or neurological deficits. } \mathrm{C}^{---} \text {mice showed } \\
\text { decreased brain tissue damage and reduced motor } \\
\text { deficits, compared to WT, after CCI. These improvements } \\
\text { were reversed if recombinant human } \mathrm{C} 4 \text { (hC4) was } \\
\text { administered to } \mathrm{C}^{---} \text {mice. }\end{array}$ \\
\hline $\begin{array}{l}\text { Longhi et al., } \\
2009 \text { [93] }\end{array}$ & Mouse & $\mathrm{CCl}$ & $\begin{array}{l}\cdot W T+C 1-I N H \\
\cdot W T\end{array}$ & $\begin{array}{l}\text { Classical and } \\
\text { lectin }\end{array}$ & $\begin{array}{l}\text { Mice given C1-INH } 10 \text { mins after injury developed } \\
\text { smaller contusions, and had reduced cognitive and } \\
\text { motor dysfunction compared to vehicle-treated controls } \\
\text { Delayed administration of C1-INH ( } 60 \text { mins post-injury) } \\
\text { led to a reduction in motor dysfunction, but had no } \\
\text { effect on cognitive deficits or contusion size. }\end{array}$ \\
\hline $\begin{array}{l}\text { Longhi et al., } \\
2014 \text { [75] }\end{array}$ & Mouse & $\mathrm{CCl}$ & $\begin{array}{l}\cdot \mathrm{MBL}^{-1-} \\
\cdot \mathrm{WT}\end{array}$ & Lectin & $\begin{array}{l}\text { MBL-C and MBL-A immunostaining was upregulated } \\
30 \text { mins post-injury, and this lasted for a week. MBL-A } \\
\text { immunostaining was less prominent. Neuronal loss in } \\
\text { MBL-A/MBL-C knockout (MBL-/-) mice was reduced } \\
\text { when compared with wildtypes } 5 \text { weeks post-injury, } \\
\text { which was paralleled by a reduction in sensorimotor } \\
\text { impairment when assessed } 2-4 \text { weeks post-lesion. }\end{array}$ \\
\hline $\begin{array}{l}\text { Yager et al., } \\
2008 \text { [94] }\end{array}$ & Mouse & $\mathrm{CCl}$ & $\begin{array}{l}\cdot \mathrm{MBL}^{-1-} \\
\cdot \mathrm{WT}\end{array}$ & Lectin & $\begin{array}{l}6 \text { hrs post-injury, increased neurodegeneration was } \\
\text { observed in the hippocampi of } \mathrm{MBL}^{--} \text {mice when } \\
\text { compared with WT mice. Neurological deficits in } \\
\mathrm{MBL}^{--/} \text {mice were also greater than those in WT } \\
\text { mice, when assessed a week after injury. }\end{array}$ \\
\hline
\end{tabular}

inhibiting C6, yielded very similar results [89]. A recent study building on these findings generated an inhibitor of MAC complex formation, composed of complement receptor of the Ig superfamily (CRIg) fused with CD59 (CD59-2a-CRIg). Administration of this inhibitor to a TBI mouse model was found to reduce MAC formation, neuronal damage and microglial activation compared to vehicle-treated controls. Paralleling this, it was found that neurological outcomes were significantly better in the mice treated with this inhibitor when compared with placebo-treated mice [90].

\section{Animal studies focusing on specific complement activation pathways}

Attempts to tease out the relative contributions to TBI secondary injury of the different complement activation pathways have been made using animal models [76] (see Table 2 for a summary). Mice lacking $\mathrm{fB}\left(\mathrm{fB}^{-/-}\right)$, whose alternative pathway of complement activation is nonfunctional, were found to have reduced neuronal loss with concomitant upregulation of the anti-apoptotic regulatory protein Bcl-2 and downregulation of the pro-apoptotic Fas receptor, compared with control mice subsequent to TBI [91]. Extending this, a study investigated the effect a monoclonal antibody directed against fB (mab1379) had when administered to control mice, which were exposed to a TBI-like injury, 1 or $24 \mathrm{~h}$ after injury. These mice displayed reduced neuronal loss, an attenuated inflammatory response, as well as upregulation of genes associated with neuroprotection when compared with vehicle-treated mice [79]. Interestingly, however, there was no difference observed between the two groups in terms of neurological function [92]. Experimental evidence has also implicated both the classical and lectin pathways in the pathogenesis of TBI. Mice lacking complement component $\mathrm{C} 4\left(\mathrm{C}^{-/-}\right)$, which is involved in both the classical and lectin pathways, and wildtype mice were subjected to a $\mathrm{CCI}$ injury. $\mathrm{C}^{-/-}$ mice showed decreased brain tissue damage and reduced motor deficits, compared to wildtypes, after CCI. These improvements were reversed if recombinant human $\mathrm{C} 4$ was administered to $\mathrm{C}^{-/-}$mice. Similarly, it was found that mice given $\mathrm{C} 1-\mathrm{INH}$ (which inhibits both the classical and lectin pathways) 10 min after the initial injury developed smaller contusions and had reduced cognitive and motor dysfunction compared to vehicle-treated controls. Delayed administration of C1-INH (60 min post-injury) led to a reduction in motor dysfunction, but had no effect on cognitive deficits or contusion size [93]. The involvement of the lectin pathway in TBI has been further investigated by immunostaining for MBL-A and MBL-C in the cortex of wildtype mice post-CCI. MBL-C immunostaining was more intense $30 \mathrm{~min}$ post-injury, and this lasted for a further week. MBL-A immunostaining was less prominent. Neuronal loss in MBL-A/MBL-C knockout (MBL-/-) mice was reduced when compared with wildtypes 5 weeks post-injury, which was paralleled by a reduction in sensorimotor impairment when assessed 24 weeks post-lesion [75]. In contrast to this, early after a 
CCI injury ( $6 \mathrm{~h}$ post-injury), increased neurodegeneration was observed in the hippocampi of $\mathrm{MBL}^{-/-}$mice when compared with WT mice. Neurological deficits in $\mathrm{MBL}^{-/-}$ mice were also greater than those in WT mice, when assessed a week after injury [94]. Thus, it may be that the lectin pathway functions in a neuroprotective capacity in the early phase of TBI secondary injury, before switching to a deleterious phenotype in the late phase.

\section{The complement system and CNS repair}

While activation of the complement system can have a number of deleterious effects in the CNS, there is evidence that it also plays a prominent role in CNS repair, protection and regeneration [95]. For example, the complement system has been implicated in neurogenesis. In the adult human, neurogenesis is believed to take place in two brain regions: the subgranular zone (SGZ) of the dentate gyrus (DG) of the hippocampus (see Fig. 3) [96] and the subventricular zone (SVZ) [86, 87] (see Fig. 4). The neuroblasts generated in the SVZ migrate, via the rostral migratory stream (RMS), to the olfactory bulb (OB) $[97,98]$. Neural precursor cells (NPCs) have been shown to express C3aRs and C5aRs [99]. In vitro studies have demonstrated that the application of C3a to NPCs enhances their maturation and migration [100]. In vivo studies have also shown that administration of a C3aR antagonist to mice results in reduced neurogenesis in the SGZ, the SVZ and the OB. Put together, these findings suggest a role for $\mathrm{C} 3 \mathrm{a} / \mathrm{C} 3 \mathrm{aR}$ in neurogenesis. Interestingly, despite the fact that SVZ NPCs appear to express $\mathrm{C} 5 \mathrm{aRs}$, C5a signaling through $\mathrm{C} 5 \mathrm{aRs}$ was not thought to play a role in SVZ neurogenesis [101], although more recent evidence suggests that C5aR1 signaling drives mouse embryonic neural progenitor cell proliferation in the SVZ by signaling via protein kinase

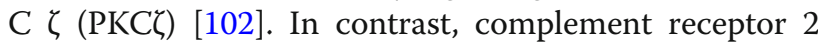
(CR2), which is expressed by DG progenitor cells, appears to inhibit neurogenesis. Evidence for this comes from CR2-deficient mice, which show increased neurogenesis, whereas C3d and interferon- $\alpha$ (IFN- $\alpha$ ) (both of which bind CR2) are associated with downregulation of neurogenesis [103].

Furthermore, evidence for a role of complement in neurogenesis induced by brain injury has emerged from both human and animal studies. In human TBI cases, it was found that neural stem cell (NSC) markers were upregulated in the cortex surrounding the lesion compared to controls, indicating that neurogenesis is induced in response to TBI [104]. A comparison between C3 null mice and control mice that were subjected to a transient ischemic insult revealed a significant reduction in SVZ neurogenesis 7 days post-insult in the $\mathrm{C} 3$ null mice. These

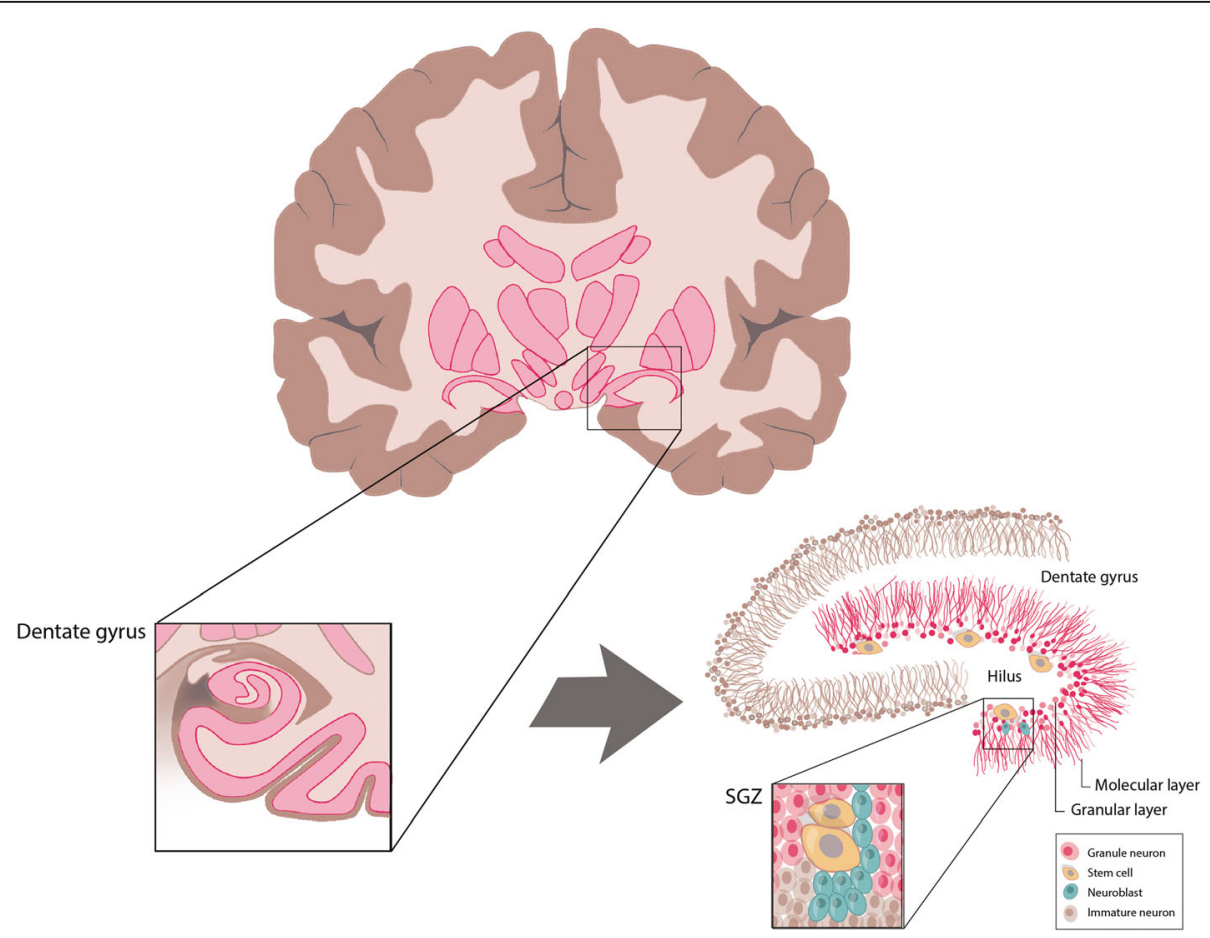

Fig. 3 Subgranular zone (SGZ) neurogenesis in the dentate gyrus (DG) of the hippocampus of the adult human brain. Coronal section (top left) through the human brain, illustrating the location of the hippocampus within the medial temporal lobe, and zoomed in view of the hippocampal formation, demonstrating its structure. Illustration of the finer structural details of the hippocampal formation (bottom right), with neural stem cells (NSCs) shown present within the SGZ. Adapted from Vescovi, Galli and Reynolds, 2006 [126] 


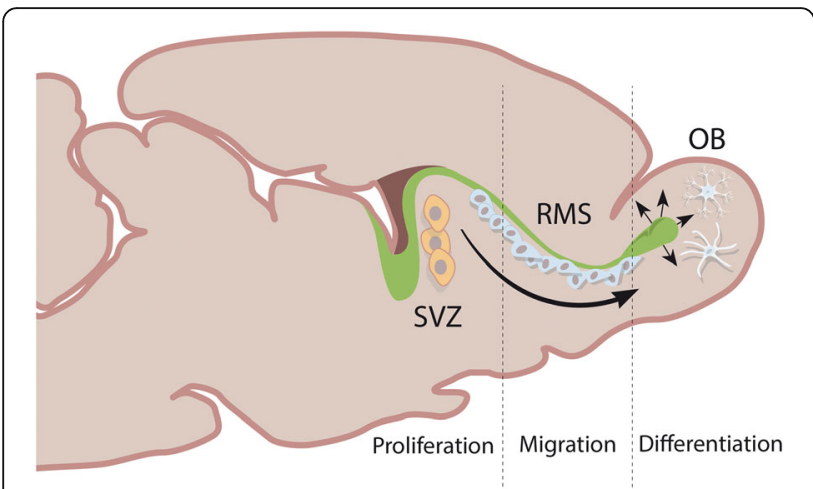

Fig. 4 Neurogenesis in the subventricular zone (SVZ). Sagittal section through the rodent brain, illustrating how NSCs generated in the SVZ migrate via the rostral migratory stream (RMSO to the olfactory bulb $(\mathrm{OB})$ ). As the cells migrate towards the $\mathrm{OB}$, they undergo terminal differentiation. Adapted from Abrous, Koehl and Moal, 2005 [127]

differences were not linked to reactive gliosis, as there was no difference between the $\mathrm{C} 3$ null and control mice in that regard [99]. Further evidence linking C3a to neurogenesis in the context of brain injury came from experiments in ischemic neonatal mice. C3a/GFAP mice subjected to neonatal hypoxic ischemia $(\mathrm{HI})$ demonstrated preserved hippocampal volume and greater levels of adult born neurons in the DG compared to wildtypes. C3a therefore exerted a protective effect on adult neurogenesis in the context of ischemia. Furthermore, as adults, animals treated with C3a peptide shortly after neonatal HI demonstrated improved memory in a cue-induced fear conditioning paradigm. In contrast, administration of C3a peptide to C3aR null ischemic neonatal mice had no effect on the aforementioned parameters [105]. Consistent with the improvement in memory function observed with C3a administration in wildtype mice is the finding that adult neurogenesis in the SGZ leads to improved learning and memory function [106-109].

A number of experiments also indicate that the complement system can have neuroprotective capabilities in the CNS [95]. Rat neurons exposed to C1q survived longer than neurons not treated with $\mathrm{C} 1 \mathrm{q}$, and they had a statistically greater number of neurites [110]. These neuroprotective effects of $\mathrm{C} 1 \mathrm{q}$ may be due to upregulation of cytoskeletal genes involved in synaptic function, increased metabolism of cholesterol, as well as upregulation of neurotrophic factors including neurotrophin 3 and nerve growth factor (NGF) [111]. Exposure of C5deficient mice to kainic acid (KA), which can act as an excitotoxin (with excitotoxicity being one of the likely mechanisms of secondary injury in TBI), resulted in greater neuronal death than in wildtype mice exposed to the same insult [112]. Thus, it appears that C5 may play a role in protecting neurons against death by excitotoxicity. A further study demonstrated that it is the C5a fragment, more specifically, that plays an important neuroprotective role. Administration of $\mathrm{C} 5 \mathrm{a}$ with KA was found to result in reduced neuronal death when compared with KA alone. Further analysis suggested that C5a achieves this via a signalling cascade that results in caspase-3 downregulation, thereby reducing apoptotic cell death [113]. C3a appears to have similar neuroprotective effects to C5a [95]. In in vitro experiments where neuronal-astrocytic co-cultures were exposed to N-methyl-D-aspartate (NMDA), which can function as another excitotoxin, concomitant application of human C3a resulted in reduced neuronal death relative to NMDA application alone. This neuroprotective effect, while facilitated by $\mathrm{C} 3 \mathrm{a}$, appeared to be mediated by the astrocytes, as it was abrogated in pure neuronal cultures (i.e. in the absence of astrocytes) [114]. While the MAC complex at higher concentrations promotes cell lysis, it appears to have neuroprotective properties at sublytic concentrations [95]. It can promote the survival of oligodendrocytes within the CNS by inhibiting their apoptosis. It was found that this effect was mediated secondary to inhibition of pro-apoptotic factors (e.g. caspase-3) and converse activation of anti-apoptotic factors (e.g. Bcl-2) [115]. Enhanced oligodendrocyte survival should reduce the extent of demyelination subsequent to an injury to the CNS, thereby aiding in the maintenance of axonal integrity. Pharmacological inhibition of phosphoinositide 3-kinase (PI3K) was found to partially reverse the pro-survival effect of sublytic concentrations of MAC on oligodendrocytes, which suggests that such concentrations of MAC may mediate these effects via a PI3K signaling pathway [116].

Furthermore, CNS glia, including microglia and astrocytes, secrete a number of neurotrophic factors in response to stimulation by complement components [95]. Consistent with this, astrocytes are known to produce NGF subsequent to CNS injury, in response to complement components (C3a and C5a) as well as cytokines (interleukin-1 $\beta$ ) $[117,118]$. Similarly, C3a has been shown to induce NGF production by microglia [119]. NGF is known to promote the survival of neurons (including cholinergic neurons) subsequent to axotomy, as well as promoting sprouting and regeneration [120]. In addition to its role in promoting neuronal regeneration, complement has been implicated in promoting not only just oligodendrocyte survival, but also proliferation, subsequent to CNS injury [121]. The mechanism appears to involve sublytic doses of the MAC inducing the oligodendrocyte cell cycle [122], by inducing an array of mitogenic and anti-apoptotic signaling pathways $[123,124]$. Enhanced oligodendrocyte proliferation would be expected to enhance neuronal myelination, thereby contributing to the maintenance of axonal integrity. Experiments comparing C5-deficient to C5-sufficient experimental autoimmune 
encephalomyelitis (EAE) mice, a multiple sclerosis (MS) model, have lent support to this notion. C5-deficient mice displayed marked reactive gliosis and Wallerian degeneration of axons. This was in stark contrast with C5-sufficient mice that were found to have significantly reduced Wallerian degeneration linked to concurrent remyelination and reduced gliosis [125]. Therefore, C5 appears to play an important facilitatory role in remyelination subsequent to brain injury, which can contribute to improved neuronal survival.

\section{Future perspectives}

A lot of progress has been made, over the past 30 years or so, in determining the role the complement system plays in TBI secondary injury. However, a multitude of questions that must be addressed by future research remain. The complement system can have both neurotoxic effects as well as neuroprotective influences subsequent to CNS injury. While the complement system appears to play a role in neurogenesis and promoting neuronal survival, including subsequent to CNS injury (e.g. in the context of excitotoxicity and experimental MS), there are few studies that have investigated this in the context of TBI secondary injury. A goal of future research should, therefore, be to address directly whether complement is involved in promoting neurogenesis and neuroprotection subsequent to TBI, e.g. by investigating this in animal models of TBI (e.g. standardized weight-drop and CCI models) as well as human TBI patients. If there is indeed evidence for a neuroprotective role of complement in TBI, then it may be possible to manipulate the complement system (e.g. pharmacologically) to promote neurogenesis/regeneration, which may in turn ameliorate the disabilities that often result from TBI. Complement may play a part in mediating plasticity after TBI, as it is known to have a developmental role in synaptic pruning, but this has not been investigated either in human TBI patients or in animal models of TBI. Thus, a future goal would be to address this, as this could provide another future target for manipulation in order to improve neurological outcomes after TBI. It would also be instructive to carry out studies that are designed to assess a greater number of endpoints, as certain complement components may function neuroprotectively early on during secondary injury but may then switch to become harmful, or vice versa. Therefore, it would be important to ascertain timelines for the actions of the different complement components, in order to work out how best to manipulate them (i.e. whether to activate them or inhibit them) and when best to do so (i.e. whether early or late in the course of the secondary injury). Finally, while attempts have been made using animal models to disentangle the influences of each of the complement activation pathways in TBI, more studies (including ones in human patients) will be required in order to shed more light on the contributions each makes to the pathophysiology of TBI.

\section{Clinical and translational perspective}

Based on current evidence in the literature, which has mainly focused on the deleterious effects of complement in the context of TBI, it appears that complement functions in a mainly damaging fashion in TBI. As discussed in the section entitled 'The complement system and CNS injury', dampening down the activity of the complement system, by various means in animal models of TBI, has been generally associated with reduced lesion sizes as well as improved neurological outcomes. Thus, it would appear that a promising future strategy for TBI management would be to target the complement system for downregulation, e.g. by administering pharmacological antagonists of various known mediators in the complement pathway. While pre-clinical studies performed in animal models have yielded promising results (with a number of therapeutics, e.g. sCR1, Crry-Ig, and SB290157, displaying some efficacy), further experiments are required to determine which pharmacological agents would be most appropriate, what doses they must be administered at, via which route(s) they must be administered, and when after the initial injury it would be best to administer them. Subsequent to that, human trials must be started in order to determine whether such agents would be both safe and useful in the target patient group.

\section{Conclusion}

TBI is a leading cause of morbidity in the western world. While healthcare advancements have resulted in a reduction in mortality associated with TBI, it is still a major cause of disability. Neurological outcomes subsequent to TBI are significantly influenced by the secondary sequelae that follow the initial injury. The secondary injury is multifaceted, involving a prominent neuroinflammatory response, in addition to ischemia, excitotoxic neuronal cell death, and free radical production. An important part of the ensuing inflammatory response is activation of the complement cascade. The complement system can have both neurotoxic and neuroprotective effects subsequent to CNS injury. As it takes time for the secondary sequelae of TBI to develop and for any resulting changes to become irreversible, this may provide a window of opportunity for interventions that may improve outcomes subsequent to TBI. One promising target for such interventions is the complement system. Pharmacological agents targeting components of the complement system have been trialed in animal models, with some promising results. Pending further investigations, it may be possible to translate such agents to clinical practice in the future, which may revolutionize the management of TBI. 


\section{Abbreviations}

BBB: Blood-brain barrier; C5aR1: C5 a receptor 1; CCl: Controlled cortical impact; CNS: Central nervous system; CR2: Complement receptor 2; CSF: Cerebrospinal fluid; CTSL: Cathepsin L; DG: Dentate gyrus; GCS: Glasgow Coma Scale; GFAP: Fibrillary acidic protein; ICH: Intracerebral haemorrhage; IFN-a: interferon-a; KA: Kainic acid; MAC: Membrane attack complex; MASPs: MBL-associated serine proteases; MBL: Mannose-binding lectin; NMDA: N-methyl-D-aspartate; PI3K: Phosphoinositide 3-kinase; PKCZ: Protein

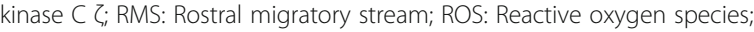
SCR1: Soluble complement receptor 1; SGZ: Subgranular zone; SVZ: Subventricular zone; TBI: Traumatic brain injury

\section{Acknowledgements}

We would like to thank Ms. Jan Sharp, Media resources Centre, University Hospital of Wales for her help in reproducing the figures.

\section{Funding}

LW is funded by Waterloo Foundation Fellowship; the funding body had no involvement in the design of the study and collection, analysis, and interpretation of data and in writing the manuscript.

\section{Availability of data and materials}

Authors confirm that all relevant data are included in the article.

\section{Authors' contributions}

$\mathrm{AH}$ carried out the literature review, participated in the sequence alignment and drafted the manuscript. LW helped to draft the manuscript. MZ conceived, designed and coordinated the study, and contributed to and finalized the draft. All authors read and approved the final manuscript.

\section{Ethics approval and consent to participate}

Not applicable.

\section{Consent for publication}

Not applicable as no patients/participants involved in this review.

\section{Competing interests}

The authors declare that they have no competing interests.

\section{Publisher's Note}

Springer Nature remains neutral with regard to jurisdictional claims in published maps and institutional affiliations.

\section{Author details}

'School of Clinical Medicine, University of Cambridge, Cambridge, UK. ${ }^{2}$ Neuroscience and Mental Health Research Institute (NMHRI), School of Medicine, Cardiff University, Room 4FT 80E, 4th Floor, Heath Park, Cardiff CF14 4XN, UK

Received: 6 October 2017 Accepted: 15 January 2018

Published online: 22 January 2018

\section{References}

1. Gardner AJ, Zafonte R. Chapter 12 - Neuroepidemiology of traumatic brain injury. In Handbook of Clinical Neurology, F.B. and D.F.S. Michael J. Aminoff, ed. (Elsevier). 2016; pp 207-223.

2. Gabbe BJ, Lyons RA, Lecky FE, Bouamra O, Woodford M, Coats TJ, Cameron PA. Comparison of mortality following hospitalisation for isolated head injury in England and Wales, and Victoria, Australia. PLoS One. 2011;6:e20545

3. Prins M, Greco T, Alexander D, Giza CC. The pathophysiology of traumatic brain injury at a glance. Dis Model Mech. 2013;dmm.011585.

4. Bellander B-M, Olafsson IH, Ghatan PH, Bro Skejo HP, Hansson L-O, Wanecek M, Svensson MA. Secondary insults following traumatic brain injury enhance complement activation in the human brain and release of the tissue damage marker S100B. Acta Neurochir. 2011:153:90-100.

5. Chesnut RM, Marshall LF, Klauber MR, Blunt BA, Baldwin N, Eisenberg HM, Jane JA, Marmarou A, Foulkes MA. The role of secondary brain injury in determining outcome from severe head injury. J Trauma. 1993;34:216-22.

6. Cederberg D, Siesjö P. What has inflammation to do with traumatic brain injury? Childs Nerv Syst. 2010;26:221.
7. Kumar A, Loane DJ. Neuroinflammation after traumatic brain injury: opportunities for therapeutic intervention. Brain Behav Immun. 2012;26: 1191-201.

8. Ransohoff RM. A polarizing question: do M1 and M2 microglia exist? Nat Neurosci. 2016;19:987-91.

9. Karve IP, Taylor JM, Crack PJ. The contribution of astrocytes and microglia to traumatic brain injury. Br J Pharm. 2016;173:692-702.

10. Pearn ML, Niesman IR, Egawa J, Sawada A, Almenar-Queralt A, Shah SB, Duckworth $J$, Head BP. Pathophysiology associated with traumatic brain injury: current treatments and potential novel therapeutics. Cell Mol Neurobiol. 2017;37:571-85.

11. Colton CA, Mott RT, Sharpe H, Xu Q, van Nostrand WE, Vitek MP. Expression profiles for macrophage alternative activation genes in $A D$ and in mouse models of AD. J Neuroinflammation. 2006;3:27.

12. Ponomarev ED, Maresz K, Tan Y, Dittel BN. CNS-derived interleukin-4 is essential for the regulation of autoimmune inflammation and induces a state of alternative activation in microglial cells. J Neurosci. 2007;27: 10714-21.

13. Butovsky O, Talpalar AE, Ben-Yaakov K, Schwartz M. Activation of microglia by aggregated $\beta$-amyloid or lipopolysaccharide impairs MHC-II expression and renders them cytotoxic whereas IFN- $\gamma$ and IL-4 render them protective. Mol Cell Neurosci. 2005:29:381-93.

14. Kigerl KA, Gensel JC, Ankeny DP, Alexander JK, Donnelly DJ, Popovich PG. Identification of two distinct macrophage subsets with divergent effects causing either neurotoxicity or regeneration in the injured mouse spinal cord. J Neurosci. 2009:29:13435-44.

15. Fumagalli S, Perego C, Pischiutta F, Zanier ER, De Simoni M-G. The ischemic environment drives microglia and macrophage function. Front Neurol. 2015;6:81.

16. Färber K, Cheung G, Mitchell D, Wallis R, Weihe E, Schwaeble W, Kettenmann $\mathrm{H}$. C1q, the recognition subcomponent of the classical pathway of complement, drives microglial activation. J Neurosci Res. 2009;15:644-52.

17. de la Rosa X, Cervera A, Kristoffersen AK, Valdés CP, Varma HM, Justicia C, Durduran T, Chamorro Á, Planas AM. Mannose-binding lectin promotes local microvascular thrombosis after transient brain ischemia in mice. Stroke. 2014:45(5):1453-9.

18. Wetherington J, Serrano G, Dingledine R. Astrocytes in the epileptic brain. Neuron. 2008:58:168-78.

19. Shlosberg D, Benifla M, Kaufer D, Friedman A. Blood-brain barrier breakdown as a therapeutic target in traumatic brain injury. Nat Rev Neurol. 2010;6:393-403.

20. Beschorner R, Nguyen TD, Gözalan F, Pedal I, Mattern R, Schluesener HJ, Meyermann R, Schwab JM. CD14 expression by activated parenchymal microglia/macrophages and infiltrating monocytes following human traumatic brain injury. Acta Neuropathol. 2002;103:541-9.

21. Jin X, Ishii H, Bai Z, Itokazu T, Yamashita T. Temporal changes in cell marker expression and cellular infiltration in a controlled cortical impact model in adult male C57BL/6 mice. PLoS One. 2012;7:e41892.

22. Bellander B-M, von Holst $H$, Fredman P, Svensson M. Activation of the complement cascade and increase of clusterin in the brain following a cortical contusion in the adult rat. J Neurosurg. 1996:85:468-75.

23. Bellander B-M, Singhrao SK, Ohlsson M, Mattsson P, Svensson M. Complement activation in the human brain after traumatic head injury. J Neurotrauma. 2001; 18:1295-311.

24. Stahel PF, Morganti-Kossmann MC, Perez D, Redaelli C, Gloor B, Trentz O, Kossmann T. Intrathecal levels of complement-derived soluble membrane attack complex (sC5b-9) correlate with blood-brain barrier dysfunction in patients with traumatic brain injury. J Neurotrauma. 2001;18:773-81.

25. Martin NA, Patwardhan RV, Alexander MJ, Africk CZ, Lee JH, Shalmon E, Hovda DA, Becker DP. Characterization of cerebral hemodynamic phases following severe head trauma: hypoperfusion, hyperemia, and vasospasm. J Neurosurg. 1997:87:9-19.

26. Olney JW. Inciting excitotoxic cytocide among central eurons. In Excitatory Amino Acids and Epilepsy, R. Schwarcz, and Y. Ben-Ari, eds. (Springer US). 1986; pp631-645.

27. Faden Al, Demediuk P, Panter SS, Vink R. The role of excitatory amino acids and NMDA receptors in traumatic brain injury. Science. 1989;244:798-800.

28. Berliocchi L, Bano D, Nicotera P. Ca2+ signals and death programmes in neurons. Phil Trans R Soc B Biol Sci. 2005;360:2255-8.

29. Nicholls DG. Mitochondrial dysfunction and glutamate excitotoxicity studied in primary neuronal cultures. Curr Mol Med. 2004;4:149-77. 
30. Cochrane CG, Unanue ER, Dixon FJ. A role of polymorphonuclear leukocytes and complement in nephrotoxic nephritis. J Exp Med. 1965;122:99-116.

31. Mathern DR, Heeger PS. Molecules great and small: the complement system. Clin J Am Soc Nephrol. 2015;CJN.06230614.

32. Ricklin D, Hajishengallis G, Yang K, Lambris JD. Complement: a key system for immune surveillance and homeostasis. Nat Immunol. 2010;11:785-97.

33. Amara U, Flierl MA, Rittirsch D, Klos A, Chen H, Acker B, Brückner UB, Nilsson B, Gebhard F, Lambris JD, Huber-Lang M. Molecular intercommunication between the complement and coagulation systems. J Immunol. 2010;185:5628-36.

34. Fearon DT, Austen KF. Properdin: binding to C $3 \mathrm{~b}$ and stabilization of the C3b-dependent C3 convertase. J Exp Med. 1975;142:856-63.

35. Morgan BP. Complement membrane attack on nucleated cells: resistance, recovery and non-lethal effects. Biochem J. 1989;264:1-14.

36. Manthey HD, Woodruff TM, Taylor SM, Monk PN. Complement component 5a (C5a). Int J Biochem Cell Biol. 2009;41:2114-7.

37. Dunkelberger JR, Song WC. Role and mechanism of action of complement in regulating T cell immunity. Mol Immunol. 2010;47:2176-86.

38. Kwan WH, van der Touw W, Heeger PS. Complement regulation of T cell immunity. Immunol Res. 2012:54(1-3):247-53.

39. Carroll MC. The complement system in regulation of adaptive immunity. Nat Immunol. 2004:5:981-6.

40. Holers VM, Kulik L. Complement receptor 2, natural antibodies and innate immunity: inter-relationships in B cell selection and activation. Mol Immunol. 2007;44:64-72.

41. Carroll MC. Complement and humoral immunity. Vaccine. 2008;26(Suppl 8):128-33.

42. Liszewski MK, Kolev M, Le Friec G, Leung M, Bertram PG, Fara AF, Subias M, Pickering MC, Drouet C, Meri S, Arstila TP, Pekkarinen PT, Ma M, Cope A, Reinheckel T, Rodriguez de Cordoba S, Afzali B, Atkinson JP, Kemper C. Intracellular complement activation sustains T cell homeostasis and mediates effector differentiation. Immunity. 2013;39:1143-57.

43. Arbore $G$, West EE, Spolski R, Robertson AAB, Klos A, Rheinheimer C, Dutow P, Woodruff TM, Yu ZX, O'Neill LA, Coll RC, Sher A, Leonard WJ, Köhl J, Monk P, Cooper MA, Arno M, Afzali B, Lachmann HJ, Cope AP, Mayer-Barber KD, Kemper C. T helper 1 immunity requires complement-driven NLRP3 inflammasome activity in CD4+ T cells. Science. 2016;352:aad1210.

44. Arbore G, Kemper C, Kolev M. Intracellular complement-the complosome-in immune cell regulation. Mol Immunol. (In press)

45. Samstad EO, Niyonzima N, Nymo S, Aune MH, Ryan L, Bakke SS, Lappegård KT, Brekke O-L, Lambris JD, Damås JK, Latz E, Mollnes TE, Espevik T. Cholesterol crystals induce complement-dependent inflammasome activation and cytokine release. J Immunol. 2014;192:2837-45.

46. Fujita T, Inoue T, Ogawa K, lida K, Tamura N. The mechanism of action of decay-accelerating factor (DAF). DAF inhibits the assembly of C3 convertases by dissociating C2a and Bb. J Exp Med. 1987;166:1221-8.

47. Cole JL, Housley GA, Dykman TR, MacDermott RP, Atkinson JP. Identification of an additional class of C3-binding membrane proteins of human peripheral blood leukocytes and cell lines. Proc Natl Acad Sci U S A. 1985;82:859-63.

48. Makou E, Herbert AP, Barlow PN. Functional anatomy of complement factor H. Biochemistry. 2013;52:3949-62.

49. Medof ME, Kinoshita T, Nussenzweig V. Inhibition of complement activation on the surface of cells after incorporation of decay-accelerating factor (DAF) into their membranes. J Exp Med. 1984;160:1558-78.

50. Lévi-Strauss M, Mallat M. Primary cultures of murine astrocytes produce C3 and factor B, two components of the alternative pathway of complement activation. J Immunol. 1987;139:2361-6.

51. Gasque P, Fontaine M, Morgan BP. Complement expression in human brain Biosynthesis of terminal pathway components and regulators in human glial cells and cell lines. J Immunol. 1995;154:4726-33.

52. Morgan BP, Gasque P. Extrahepatic complement biosynthesis: where, when and why? Clin Exp Immunol. 1997;107:1-7.

53. Ames RS, Li Y, Sarau HM, Nuthulaganti P, Foley JJ, Ellis C, Zeng Z, Su K, Jurewicz AJ, Hertzberg RP, Bergsma DJ, Kumar C. Molecular cloning and characterization of the human anaphylatoxin C3a receptor. J Biol Chem. 1996;271:20231-4

54. Nataf S, Stahel PF, Davoust N, Barnum SR. Complement anaphylatoxin receptors on neurons: new tricks for old receptors? Trends Neurosci. 1999;22:397-402.

55. Nataf S, Levison SW, Barnum SR. Expression of the anaphylatoxin C5a receptor in the oligodendrocyte lineage. Brain Res. 2001;894:321-6.

56. Alawieh A, Elvington A, Tomlinson S. Complement in the homeostatic and ischemic brain. Front Immunol. 2015;6:417.
57. Rogers J, Strohmeyer R, Kovelowski CJ, Li R. Microglia and inflammatory mechanisms in the clearance of amyloid $\beta$ peptide. Glia. 2002;40:260-9.

58. Rupprecht TA, Angele B, Klein M, Heesemann J, Pfister H-W, Botto M, Koedel U. Complement C1q and C3 are critical for the innate immune response to Streptococcus pneumoniae in the central nervous system. J Immunol. 2007;178:1861-9.

59. Boos L, Szalai AJ, Barnum SR. C3a expressed in the central nervous system protects against LPS-induced shock. Neurosci Lett. 2005;387:68-71.

60. Stahel PF, Bamum SR. Bacterial meningitis: complement gene expression in the central nervous system. Immunopharmacology. 1997;38:65-72.

61. van Beek J, Elward K, Gasque P. Activation of complement in the central nervous system. Ann N Y Acad Sci. 2003;992:56-71.

62. Stevens B, Allen NJ, Vazquez LE, Howell GR, Christopherson KS, Nouri N, Micheva KD, Mehalow AK, Huberman AD, Stafford B, Sher A, Litke AM, Lambris JD, Smith SJ, John SWM, Barres BA. The classical complement cascade mediates CNS synapse elimination. Cell. 2007;131:1164-78.

63. Stephan AH, Barres BA, Stevens B. The complement system: an unexpected role in synaptic pruning during development and disease. Ann Rev Neurosci. 2012;35:369-89.

64. Schafer DP, Lehrman EK, Kautzman AG, Koyama R, Mardinly AR, Yamasaki R, Ransohoff RM, Greenberg ME, Barres BA, Stevens B. Microglia sculpt postnatal neural circuits in an activity and complement-dependent manner. Neuron. 2012;74:691-705.

65. Chu Y, Jin X, Parada I, Pesic A, Stevens B, Barres B, Prince DA. Enhanced synaptic connectivity and epilepsy in C1q knockout mice. Proc Natl Acad Sci U S A. 2010;107:7975-80.

66. Shi Q, Colodner KJ, Matousek SB, Merry K, Hong S, Kenison JE, Frost JL, Le KX, Li S, Dodart J-C, Caldarone BJ, Stevens B, Lemere CA. Complement C3deficient mice fail to display age-related hippocampal decline. J Neurosci. 2015:35:13029-42.

67. Bénard M, Gonzalez BJ, Schouft M-T, Falluel-Morel A, Vaudry D, Chan P, Vaudry $\mathrm{H}$, Fontaine $\mathrm{M}$. Characterization of $\mathrm{C} 3 \mathrm{a}$ and $\mathrm{C} 5 \mathrm{a}$ receptors in rat cerebellar granule neurons during maturation neuroprotective effect of $\mathrm{C} 5 \mathrm{a}$ against apoptotic cell death. J Biol Chem. 2004;279:43487-96.

68. Bénard M, Raoult E, Vaudry D, Leprince J, Falluel-Morel A, Gonzalez BJ, Galas L, Vaudry H, Fontaine M. Role of complement anaphylatoxin receptors (C3aR, C5aR) in the development of the rat cerebellum. Mol Immunol. 2008:45:3767-74.

69. Brennan FH, Anderson AJ, Taylor SM, Woodruff TM, Ruitenberg MJ. Complement activation in the injured central nervous system: another dualedged sword? J Neuroinflammation. 2012;9:137

70. Ankeny DP, Guan Z, Popovich PG. B cells produce pathogenic antibodies and impair recovery after spinal cord injury in mice. J Clin Invest. 2009;119:2990-9.

71. Nguyen HX, Galvan MD, Anderson AJ. Characterization of early and terminal complement proteins associated with polymorphonuclear leukocytes in vitro and in vivo after spinal cord injury. J Neuroinflammation. 2008;5:26.

72. Qiao F, Atkinson C, Kindy MS, Shunmugavel A, Morgan BP, Song H, Tomlinson S. The alternative and terminal pathways of complement mediate post-traumatic spinal cord inflammation and injury. Am J Pathol. 2010;177:3061-70

73. Stahel PF, Morganti-Kossmann MC, Kossmann T. The role of the complement system in traumatic brain injury. Brain Res Rev. 1998;27:243-56.

74. Kossmann T, Stahel PF, Morganti-Kossmann MC, Jones JL, Barnum SR. Elevated levels of the complement components C3 and factor B in ventricular cerebrospinal fluid of patients with traumatic brain injury. J Neuroimmunol. 1997;73:63-9.

75. Longhi L, Orsini F, De Blasio D, Fumagalli S, Ortolano F, Locatelli M, Stocchetti N, De Simoni M-G. Mannose-binding Lectin is expressed after clinical and experimental traumatic brain injury and its deletion is protective. Crit Care Med. 2014:42:1910-8.

76. Orsini F, De Blasio D, Zangari R, Zanier ER, De Simoni M-G. Versatility of the complement system in neuroinflammation, neurodegeneration and brain homeostasis. Front Cell Neurosci. 2014;8:380.

77. Xiong Y, Mahmood A, Chopp M. Animal models of traumatic brain injury. Nat Rev Neurosci. 2013;14(2):128-42.

78. Manley GT, Rosenthal G, Lam M, Morabito D, Yan D, Derugin N, Bollen A. M. Knudson M, Panter SS. Controlled cortical impact in swine: pathophysiology and biomechanics. J Neurotrauma. 2006;23(2):128-39.

79. Kaczorowski SL, Schiding JK, Toth CA, Kochanek PM. Effect of soluble complement receptor-1 on neutrophil accumulation after traumatic brain injury in rats. J Cereb Blood Flow Metab. 1995;15:860-4. 
80. Yang S, Nakamura T, Hua Y, Keep RF, Younger JG, He Y, Hoff JT, Xi G. The role of complement C3 in intracerebral hemorrhage-induced brain injury. J Cereb Blood Flow Metab. 2006;26:1490-5.

81. Sewell DL, Nacewicz B, Liu F, Macvilay S, Erdei A, Lambris JD, Sandor M, Fabry Z. Complement C3 and C5 play critical roles in traumatic brain cryoinjury: blocking effects on neutrophil extravasation by $\mathrm{C} 5$ a receptor antagonist. J Neuroimmunol. 2004;155:55-63.

82. You Z, Yang J, Takahashi K, Yager PH, Kim H-H, Qin T, Stahl GL, Ezekowitz RAB, Carroll MC, Whalen MJ. Reduced tissue damage and improved recovery of motor function after traumatic brain injury in mice deficient in complement component C4. J Cereb Blood Flow Metab. 2007;27:1954-64.

83. Rancan M, Morganti-Kossmann MC, Barnum SR, Saft S, Schmidt Ol, Ertel W Stahel PF. Central nervous system-targeted complement inhibition mediates neuroprotection after closed head injury in transgenic mice. J Cereb Blood Flow Metabol. 2003;23:1070-4.

84. Leinhase I, Schmidt OI, Thurman JM, Hossini AM, Rozanski M, Taha ME, Scheffler A, John T, Smith WR, Holers VM, Stahel PF. Pharmacological complement inhibition at the C3 convertase level promotes neuronal survival, neuroprotective intracerebral gene expression, and neurological outcome after traumatic brain injury. Exp Neurol. 2006;199:454-64.

85. Garrett MC, Otten ML, Starke RM, Komotar RJ, Magotti P, Lambris JD, Rynkowski MA, Connolly ES. Synergistic neuroprotective effects of C3a and C5a receptor blockade following intracerebral hemorrhage. Brain Res. 2009;1298:171-7.

86. Mathieu M-C, Sawyer N, Greig GM, Hamel M, Kargman S, Ducharme Y, Lau CK, Friesen RW, O'Neill GP, Gervais FG, Therien AG. The C3a receptor antagonist SB 290157 has agonist activity. Immunol Lett. 2005;100:139-45.

87. Therien AG. Agonist activity of the small molecule C3aR ligand SB 290157. J Immunol. 2005;174:7479-80.

88. Stahel PF, Flierl MA, Morgan BP, Persigehl I, Stoll C, Conrad C, Touban BM, Smith WR, Beauchamp K, Schmidt OI, Ertel W, Leinhase I. Absence of the complement regulatory molecule CD59a leads to exacerbated neuropathology after traumatic brain injury in mice. J Neuroinflammation. 2009;6:2.

89. Fluiter K, Opperhuizen AL, Morgan BP, Baas F, Ramaglia V. Inhibition of the membrane attack complex of the complement system reduces secondary neuroaxonal loss and promotes neurologic recovery after traumatic brain injury in mice. J Immunol. 2014;192:2339-48.

90. Ruseva MM, Ramaglia V, Morgan BP, Harris C. An anticomplement agent that homes to the damaged brain and promotes recovery after traumatic brain injury in mice. Proc Natl Acad Sci U S A. 2015;112:14319-24.

91. Leinhase I, Holers VM, Thurman JM, Harhausen D, Schmidt OI, Pietzcker M, Taha ME, Rittirsch D, Huber-Lang M, Smith WR, Ward PA, Stahel PF. Reduced neuronal cell death after experimental brain injury in mice lacking a functional alternative pathway of complement activation. BMC Neurosci. 2006:7:55

92. Leinhase I, Rozanski M, Harhausen D, Thurman JM, Schmidt OI, Hossini AM, Taha ME, Rittirsch D, Ward PA, Holers VM, Ertel W, Stahel PF. Inhibition of the alternative complement activation pathway in traumatic brain injury by a monoclonal anti-factor B antibody: a randomized placebo-controlled study in mice. J Neuroinflammation. 2007:4:13.

93. Longhi L, Perego C, Ortolano F, Zanier ER, Bianchi P, Stocchetti N, Mclntosh TK, De Simoni MG. C1-inhibitor attenuates neurobehavioral deficits and reduces contusion volume after controlled cortical impact brain injury in mice. Crit Care Med. 2009;37:659-65.

94. Yager PH, You Z, Qin T, Kim H-H, Takahashi K, Ezekowitz AB, Stahl GL, Carroll MC, Whalen MJ. Mannose binding lectin gene deficiency increases susceptibility to traumatic brain injury in mice. J Cereb Blood Flow Metab. 2008;28:1030-9.

95. Rutkowski MJ, Sughrue ME, Kane AJ, Mills SA, Fang S, Parsa AT. Complement and the central nervous system: emerging roles in development, protection and regeneration. Immunol Cell Biol. 2010;88:781-6.

96. Knoth R, Singec I, Ditter M, Pantazis G, Capetian P, Meyer RP, Horvat V, Volk B, Kempermann G. Murine features of neurogenesis in the human hippocampus across the lifespan from 0 to 100 years. PLoS One. 2010;5:e8809.

97. Sanai N, Nguyen T, Ihrie RA, Mirzadeh Z, Tsai H-H, Wong M, Gupta N, Berger MS, Huang E, Garcia-Verdugo J-M, Rowitch DH, Alvarez-Buylla A. Corridors of migrating neurons in the human brain and their decline during infancy. Nature. 2011:478:382-6.

98. Wang C, Liu F, Liu Y-Y, Zhao C-H, You Y, Wang L, Zhang J, Wei B, Ma T, Zhang Q, Zhang Y, Chen R, Song H, Yang Z. Identification and characterization of neuroblasts in the subventricular zone and rostral migratory stream of the adult human brain. Cell Res. 2011;21:1534-50.
99. Rahpeymai Y, Hietala MA, Wilhelmsson U, Fotheringham A, Davies I, Nilsson AK, Zwirner J, Wetsel RA, Gerard C, Pekny M, Pekna M. Complement: a novel factor in basal and ischemia-induced neurogenesis. EMBO J. 2006;25:1364-74.

100. Shinjyo N, Ståhlberg A, Dragunow M, Pekny M, Pekna M. Complementderived anaphylatoxin C3a regulates in vitro differentiation and migration of neural progenitor cells. Stem Cells. 2009;27:2824-32.

101. Bogestål YR, Barnum SR, Smith PLP, Mattisson V, Pekny M, Pekna M. Signaling through C5aR is not involved in basal neurogenesis. J Neurosci Res. 2007;85:2892-7.

102. Coulthard LG, Hawksworth OA, Li R, Balachandran A, Lee JD, Sepehrband F, Kurniawan $N$, Jeanes A, Simmons DG, Wolvetang $E_{\text {, }}$ Woodruff TM. Complement C5aR1 signaling promotes polarization and proliferation of embryonic neural progenitor cells through PKCद. J Neurosci. 2017;37(22):5395-407.

103. Moriyama M, Fukuhara T, Britschgi M, He $Y$, Narasimhan R, Villeda S, Molina H, Huber BT, Holers M, Wyss-Coray T. Complement receptor 2 is expressed in neural progenitor cells and regulates adult hippocampal neurogenesis. J Neurosci. 2011;31:3981-9.

104. Zheng W, ZhuGe Q, Zhong M, Chen G, Shao B, Wang H, Mao X, Xie L, Jin K. Neurogenesis in adult human brain after traumatic brain injury. J Neurotrauma. 2013:30:1872-80.

105. Järlestedt K, Rousset Cl, Ståhlberg A, Sourkova H, Atkins AL, Thornton C, Barnum SR, Wetsel RA, Dragunow M, Pekny M, Mallard C, Hagberg H, Pekna M. Receptor for complement peptide C3a: a therapeutic target for neonatal hypoxic-ischemic brain injury. FASEB J. 2013;27:3797-804.

106. Shors TJ, Townsend DA, Zhao M, Kozorovitskiy Y, Gould E. Neurogenesis may relate to some but not all types of hippocampal-dependent learning. Hippocampus. 2002;12:578-84

107. Winocur G, Wojtowicz JM, Sekeres M, Snyder JS, Wang S. Inhibition of neurogenesis interferes with hippocampus-dependent memory function. Hippocampus. 2006;16:296-304.

108. Saxe MD, Battaglia F, Wang J-W, Malleret G, David DJ, Monckton JE, Garcia ADR, Sofroniew MV, Kandel ER, Santarelli L, Hen R, Drew MR. Ablation of hippocampal neurogenesis impairs contextual fear conditioning and synaptic plasticity in the dentate gyrus. Proc Natl Acad Sci U S A. 2006;103:17501-6.

109. Dupret D, Revest J-M, Koehl M, Ichas F, Giorgi FD, Costet P, Abrous DN, Piazza PV. Spatial relational memory requires Hippocampal adult Neurogenesis. PLoS One. 2008;3:e1959.

110. Pisalyaput K, Tenner AJ. Complement component C1q inhibits betaamyloid- and serum amyloid P-induced neurotoxicity via caspase- and calpain-independent mechanisms. J Neurochem. 2008;104:696-707.

111. Benoit ME, Tenner AJ. Complement protein C1q-mediated neuroprotection is correlated with regulation of neuronal gene and microRNA expression. J Neurosci. 2011:31:3459-69.

112. Pasinetti GM, Tocco G, Sakhi S, Musleh WD, DeSimoni MG, Mascarucci $P$, Schreiber S, Baudry M, Finch CE. Hereditary deficiencies in complement C5 are associated with intensified neurodegenerative responses that implicate new roles for the C-system in neuronal and astrocytic functions. Neurobiol Dis. 1996:3:197-204.

113. Osaka H, Mukherjee P, Aisen PS, Pasinetti GM. Complement-derived anaphylatoxin C5a protects against glutamate-mediated neurotoxicity. J Cell Biochem. 1999;73:303-11.

114. van Beek J, Nicole O, Ali C, Ischenko A, MacKenzie ET, Buisson A, Fontaine M. Complement anaphylatoxin C3a is selectively protective against NMDAinduced neuronal cell death. Neuroreport. 2001;12:289-93.

115. Soane L, Rus H, Niculescu F, Shin ML. Inhibition of oligodendrocyte apoptosis by sublytic C $5 b-9$ is associated with enhanced synthesis of $\mathrm{BCl}-2$ and mediated by inhibition of Caspase-3 activation. J Immunol. 1999;163:6132-8.

116. Cudrici C, Niculescu F, Jensen T, Zafranskaia E, Fosbrink M, Rus V, Shin ML, Rus H. C5b-9 terminal complex protects oligodendrocytes from apoptotic cell death by inhibiting caspase-8 processing and up-regulating FLIP. J Immunol. 2006;176:3173-80.

117. Oderfeld-Nowak B, Bacia A, Grdkowska M, Fusco M, Vantini G, Leon A, Aloe $L$. In vivo activated brain astrocytes may produce and secrete nerve growth factor-like molecules. Neurochem Int. 1992;21:455-61.

118. Jauneau A, Ischenko A, Chatagner A, Benard M, Chan P, Schouft M, Patte C, Vaudry $\mathrm{H}$, Fontaine $\mathrm{M}$. Interleukin-1 $\beta$ and anaphylatoxins exert a synergistic effect on NGF expression by astrocytes. J Neuroinflammation. 2006;3:8.

119. Heese $K$, Hock C, Otten U. Inflammatory signals induce neurotrophin expression in human microglial cells. J Neurochem. 1998;70:699-707. 
120. Ramirez JJ, Caldwell JL, Majure M, Wessner DR, Klein RL, Meyer EM, King MA. Adeno-associated virus vector expressing nerve growth factor enhances cholinergic axonal sprouting after cortical injury in rats. J Neurosci. 2003:23:2797-803.

121. Ludwin SK. Proliferation of mature oligodendrocytes after trauma to the central nervous system. Nature. 1984;308:274-5.

122. Rus HG, Niculescu F, Shin ML. Sublytic complement attack induces cell cycle in oligodendrocytes. J Immunol. 1996;156:4892-900.

123. Fosbrink $M$, Niculescu F, Rus $H$. The role of C5b-9 terminal complement complex in activation of the cell cycle and transcription. Immunol Res. 2005;31:37-46.

124. Rus HG, Niculescu Fl, Shin ML. Role of the C5b-9 complement complex in cell cycle and apoptosis. Immunol Rev. 2001;180:49-55.

125. Weerth SH, Rus H, Shin ML, Raine CS. Complement C5 in experimental autoimmune encephalomyelitis (EAE) facilitates remyelination and prevents Gliosis. Am J Pathol. 2003;163:1069-80.

126. Vescovi AL, Galli R, Reynolds BA. Brain tumour stem cells. Nat Rev Cancer. 2006;6:425-36.

127. Abrous DN, Koehl M, Moal ML. Adult Neurogenesis: from precursors to network and physiology. Physiol Rev. 2005;85:523-69.

Submit your next manuscript to BioMed Central and we will help you at every step:

- We accept pre-submission inquiries

- Our selector tool helps you to find the most relevant journal

- We provide round the clock customer support

- Convenient online submission

- Thorough peer review

- Inclusion in PubMed and all major indexing services

- Maximum visibility for your research

Submit your manuscript at www.biomedcentral.com/submit
Biomed Central 